\title{
Waarderingswoord
}

\section{Amie van Wyk - \\ Redakteur van In die Skriflig, 1987-2000}

Fika J. van Rensburg

Redakteur: In die Skriflig

Jan Harm (Amie) van Wyk het die afgelope jare feitlik sinoniem met In die Skriflig geword. Vir bykans 'n dekade en 'n half was hy redakteur van die tydskrif. In hierdie tyd het In die Skriflig 'n teologies-wetenskaplike tydskrif van formaat geword. Die tydskrif is in 1990 vanweë die redakteur se inisiatiewe geakkrediteer, en word tans in 3 internasionale elektroniese indekse geïndekseer.

Langs hierdie weg wil die redaksie van In die Skriflig en die GTV Hoofbestuur hulle groot waardering uitspreek vir die onbaatsugtige werk wat prof. Van Wyk in en deur die tydskrif gedoen het.

Amie van Wyk is op 1 April 1937 op die plaas Seekoegat in die distrik Venterstad gebore. Hy is getroud met Ria Kruger, ook van Venterstad. Hulle het drie kinders (waarvan twee nog leef), en sewe kleinkinders.

As sportman het hy ook sy bydrae gelewer: hy speel in 1956 vir die WesTransvaal o/19-span, en daarna vir etlike jare vir die PUK se eerste rugbyspan (1957-1960). Hy speel tans nog tennis, en was in 1994 in die Noord-Transvaalse veterane-tennisspan.

Hy het in 1957 die B.A.-graad aan die PU vir CHO met lof behaal, met Hebreeus en Filosofie as sy hoofvakke. Hy behaal ook die Honneurs B.A. in Filosofie (1959), en die Th.B. (1961), telkens met lof. Vir die tydperk 1962-1965 was hy predikant van die Gereformeerde Kerk Salisbury (tans Harare), en vir die tydperk 1965-1973 van die Gereformeerde Kerk Johannesburg-Sentraal. In hierdie tyd studeer hy ook aan die Vrije Universiteit Amsterdam in Nederland (1969). In 1971 slaag hy sy doktoraal met lof aan die PU vir CHO met 'n skripsie oor: Etiek in 'n eeu van tegnologie en tegnokrasie. Van 1973 tot 1981 was hy predikant 
van die Gereformeerde Kerk Stellenbosch/Strand. In 1974 voltooi hy sy proefskrif aan die PU vir CHO, met as titel: Etiek van vrede: 'n Teologiesetiese evaluering van die Christenpasifisme. Sedert 1981 is hy professor, eers aan die Hammanskraalse Teologiese Skool (tot 1994), en sedert 1994 aan die Potchefstroomse Teologiese Skool en die Fakulteit Teologie van die $\mathrm{PU}$ vir $\mathrm{CHO}$. Gedurende 1996 doen hy navorsing aan die Universiteit van Tübingen oor die etiek van Augustinus.

Oor die jare het hy op talle deputaatskappe gedien, waaronder Volkereverhoudinge en Ekumeniese Sake. Afgesien van talle artikels in geakkrediteerde tydskrifte en verskeie populêre artikels, het hy nie minder nie as tien boeke gepubliseer. Verder het hy artikels op versoek geskryf vir feesbundels aan proff. B.J. Engelbrecht (1988), W.D. Jonker (1989), J.A. Heyns (1995) en J.H. Koekemoer (2000).

Hy is ook tans redaksielid van Woord en Daad en ondervoorsitter van REBSA.

Die gereformeerde teologie is nasionaal en internasionaal ryker vanweë die besondere bydrae wat Amie van Wyk in en deur In die Skriflig gelewer het. Sy gereelde lesers sien uit na sy pennevrug in die jare wat voorlê. 